\title{
Trends in diabetes mortality identified from death certificates in Colombia, 1979-2017
}

\author{
Pablo Chaparro-Narváez¹, Nelson J. Alvis-Zakzuk¹, Diana Díaz-Jiménez¹, Carlos Castañeda-Orjuela ${ }^{1}$
}

Suggested citation Chaparro-Narváez P, Alvis-Zakzuk NJ, Díaz-Jiménez D, Castañeda-Orjuela C. Trends in diabetes mortality identified from death certificates in Colombia, 1979-2017. Rev Panam Salud Publica. 2021;45:e13. https://doi.org/10.26633/RPSP.2021.13

ABSTRACT Objective. To describe the mortality trends of diabetes mellitus (DM) in Colombia, by sex and age group, from 1979 to 2017.

Methods. We carried out an ecological study using mortality data from the Colombian National Administrative Department of Statistics. Crude and age-standardized annual mortality rates per 100000 people were estimated. Trends of standardized rates were described by sex and age groups. Joinpoint regression models were performed to study mortality trends.

Results. Throughout the whole period, the total number of DM recorded deaths in Colombia was 200650 , $58 \%(116316)$ in women $(p<0.05)$. The age-standardized mortality rates (ASMR) by sex increased from 13.2 to 26.6 deaths per 100000 in women and from 10.1 to 22.7 in men from 1979 to 1999. We observed a decrease from 26.6 to 15.4 per 100000 in women, and from 22.7 to 15.9 in men for the period 1999-2017. The joinpoint regression analysis showed that the average annual percentage change of the period did not vary in both sexes (men: $-0.2 \%, 95 \% \mathrm{Cl}-1.0$ to $1.4 \%$; women: $0.7 \%, 95 \% \mathrm{Cl}-0.1$ to $1.6 \%$ ).

Conclusions. The DM mortality showed a decreasing trend after 2000 in women and 2004 in men. Primary and secondary prevention programs must continue to be strengthened for an earlier diagnosis of diabetes.

Keywords Diabetes mellitus; mortality; epidemiology; Colombia.

Diabetes Mellitus (DM) is an important public health issue among chronic non-communicable diseases, presenting a high epidemiological and economic burden for individuals and society, especially in middle income settings (1). DM affects an estimated 463 million people, for a global prevalence of $9.3 \%$ in 2019 (1). A person with DM has higher risk of several complications that increase their mortality risk (2). DM and its complications cause economic losses in people with the disease, their families, health systems and national economies through the direct medical costs and productivity loss (3). Type $2 \mathrm{DM}$ is the most common kind of DM. Low levels of physical activity and excessive calorie consumption increase its incidence (4).

Estimates have indicated that worldwide mortality due to DM has been increasing (5). For 2017, four million people died from DM around the world, 209718 individuals in South and Central America, and 17038 in Colombia (6). Several studies have examined the epidemiological aspects of DM in Colombia; however, very few have showed trends in mortality (7). We aimed to describe the DM mortality trend in Colombia, by sex and age group, for the period 1979-2017.

\section{METHODS}

We conducted an ecological study to describe trends in mortality from DM in Colombia by sex and age groups, in the period 1979-2017. We obtained DM mortality data from individual death certificate records of the National Statistics Department (Departamento Administrativo Nacional de Estadística, DANE in

\footnotetext{
1 Instituto Nacional de Salud, Bogotá, Colombia $\square$ Nelson J. Alvis Zakzuk, alviszakzuk@gmail.com
} 
Spanish), which collects vital statistics in Colombia (8). We analyzed anonymized mortality records coded as DM according to the International Classification of Diseases, $9^{\text {th }}$ revision (250, $648.0,778.1$ ) (9) for $1979-1996$ and the $10^{\text {th }}$ revision (E10-E14, O24, P70.2) (10) for 1997-2017 considering only the underlying cause of death. The population data was extracted from projections based on the 2005 Colombian Census for 1985-2017 (11). During 1979-1984 period, we calculated the population data using simple linear regression, based on census projections. The variables considered were year of registration of death, number of deaths per year, sex, age, and underlying cause of death.

We estimated crude, standardize, and age-standardized mortality rates (ASMR) per 100000 people per year. We analyzed decennial age-groups (0-9, 10-19, 20-29, 30-39, 40-49, 50-59, $60-69,70-79$ and $\geq 80$ years old), and standardized the mortality using the direct method, taking the 2001 World Health Organization (WHO) standard population as the reference population (12).

We modeled the mortality rates trend by sex and age through Poisson joinpoint regression models, using ASMR. This type of models fits a series of combined straight lines to trend temporal data, which indicates whether mortality rate is best explicated by a single or several trend segments (13). The joinpoint regression calculates the annual percentage change (APC) and the average annual percentage change (AAPC). The statistical significance was assumed as 0.05 .
Using the Methodology for Characterizing Trends of the National Cancer Institute of the United States (14), we considered trends in this study as rates "changing less than or equal to $0.5 \%$ per year $(-0.5 \leq \mathrm{APC} \leq 0.5)$, and the APC was not statistically significant, we characterized it as stable; changing more than $0.5 \%$ per year $(\mathrm{APC}<-0.5$ or $\mathrm{APC}>0.5)$, and the APC was not statistically significant, we characterized it as non-significant change; changing with a statistically significant $\mathrm{APC}>0$, we characterized it as rising; and changing with a statistically significant APC $<0$, we characterized it as falling" (14). Data processing were performed on Microsoft Excel ${ }^{\circledast}$. Statistical analyses were performed in Stata $12^{\mathrm{TM}}$ (Stata Corporation, College Station, TX, USA) and Joinpoint Regression version 4.6.0.0 (15).

The study met the ethical requirements established by the Colombian regulations, framed in Resolution 8430 of 1993 of the Ministry of Health, whose article 11 classifies this study as "no risk" research, because only secondary data is include and individual identification is not possible.

\section{RESULTS}

Throughout the entire timeframe, the total number of DM recorded deaths in Colombia was 200 650, 58\% (116 316) in women $(p<0.05)$. The annual average of deaths was 5145 deaths. The men:women ratio was 1:1.4. During the study period, the men/women proportion decreased (Figure 1).

70

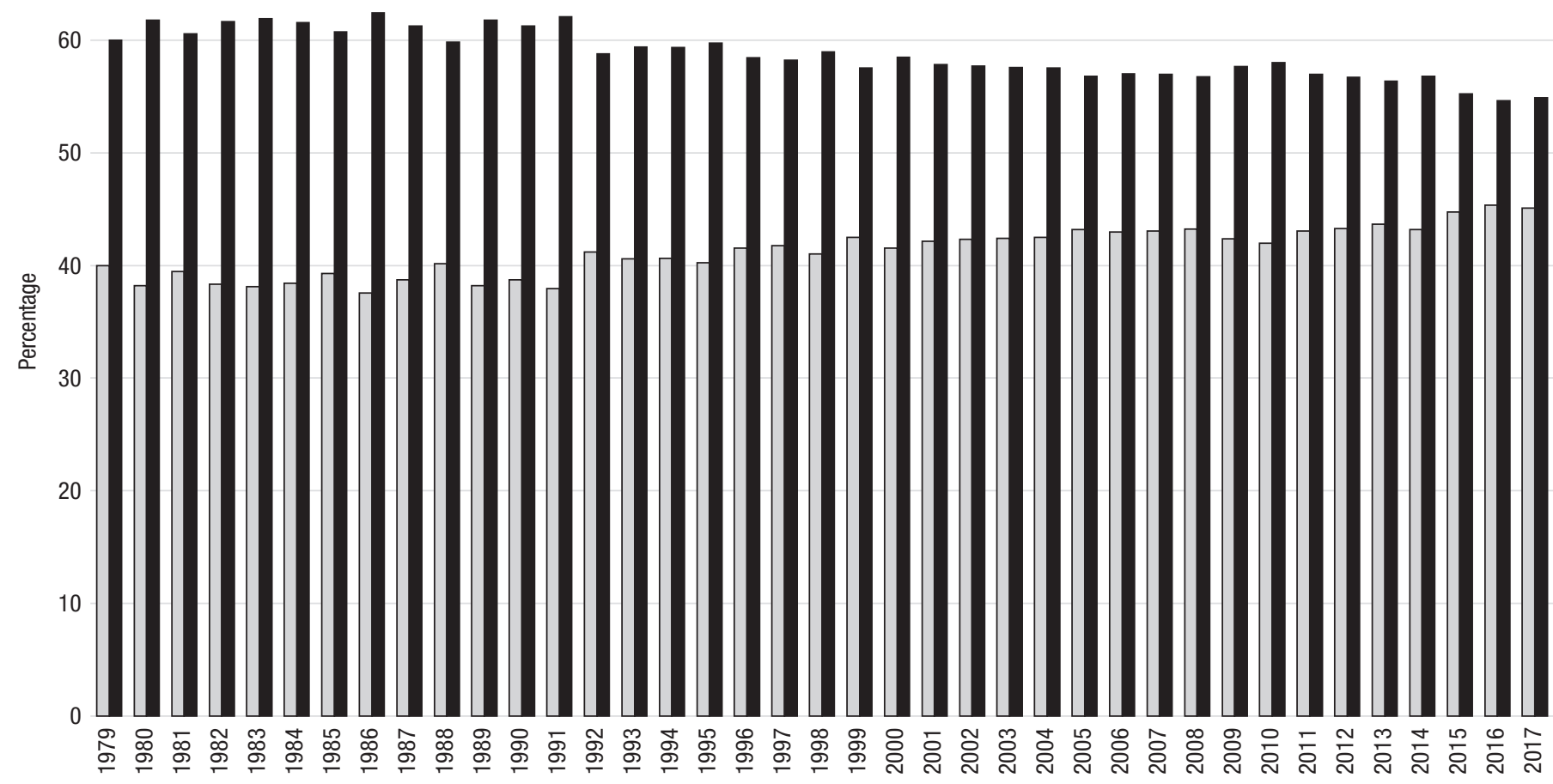

$\square$ Men $\quad$ Women 
TABLE 1. Crude and age-standardized mortality rates due to diabetes mellitus, Colombia, 1979-2017

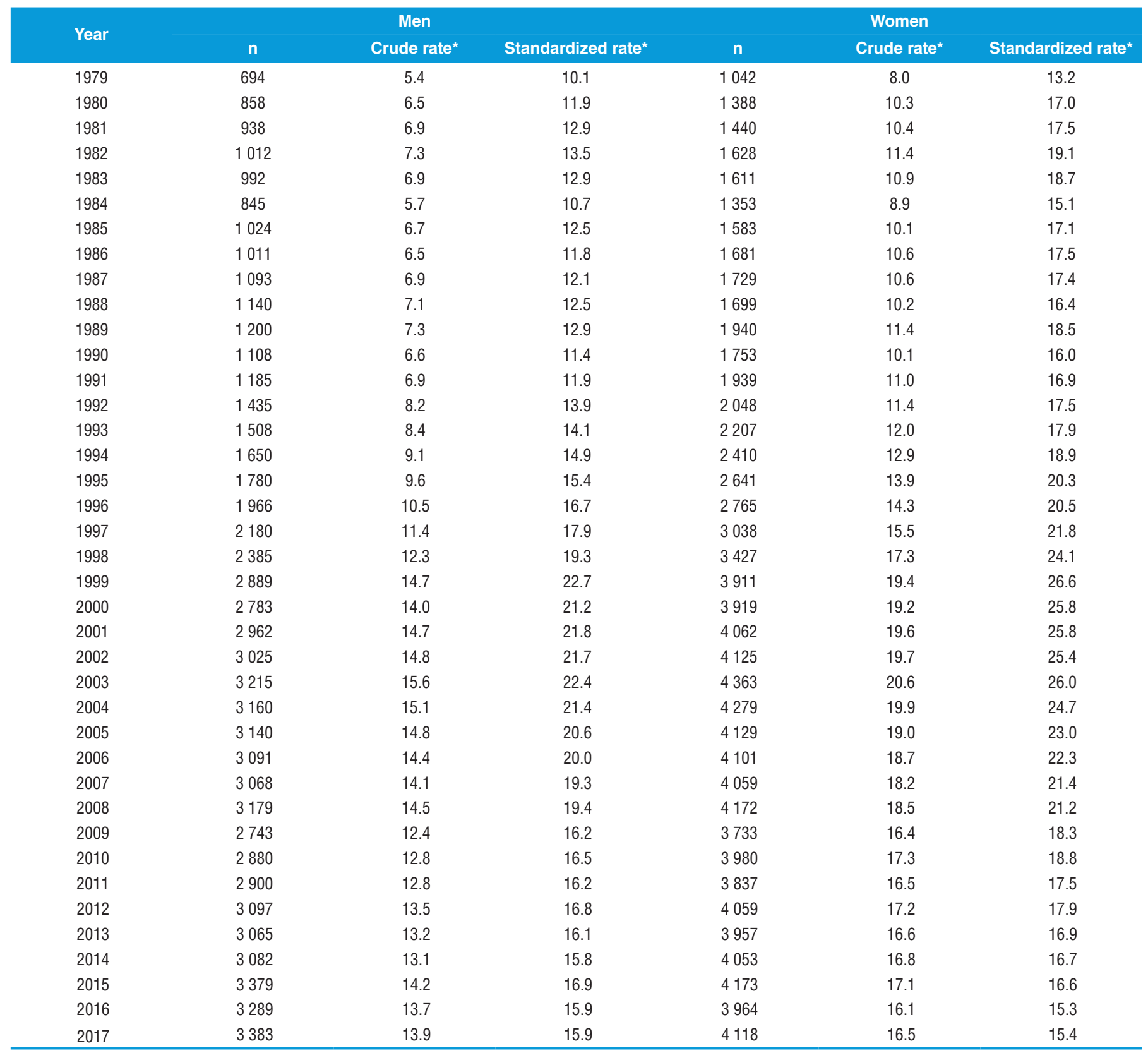

Source: prepared by the authors from the results of the study.

${ }^{*}$ Rates per 100000 individuals

The ASMR by sex increased from 13.2 to 26.6 deaths per 100 000 in women and from 10.1 to 22.7 per 100000 in men from 1979 to 1999 . We observed a decrease from 26.6 to 15.4 per 100 000 in women, and from 22.7 to 15.9 per 100000 in men for the period 1999-2017 (Table 1 and Figure 2).

Figure 3 shows the DM ASMR by sex and age groups. ASMRs were greater in women. ASMR shows an increase from $>50$ years old, for both sexes (Figure 3 ). The trend of ASMRs indicated that as age increases, rates become higher; in men $\geq 80$ years ASMRs evidenced a constant rise, while in women for the same age group the trend slightly decreased (Figure 4).
The joinpoint regression analysis showed that the AAPC of the period did not vary in both sexes (men: $-0.2 \%, 95 \%$ CI -1.0 to $1.4 \%$; women: $0.7 \%, 95 \% \mathrm{CI}:-0.1$ to $1.6 \%$ ). In men, a significant increase in ASMRs was identified for the period 1991-1999 (APC 7.3\%, 95\% CI 5.3 to 9.4\%), and a significant decrease was found for $2004-2010$ (APC $-4.7 \%, 95 \%$ CI -7.0 to $-2.3 \%$ ) per year. A joinpoint trend was detected for women for the period 19922000, where ASMRs rose by $6.3 \%$ (95\% CI 4.5 to $8.1 \%$ ); however, ASMRs fell by $3.5 \%$ (APC $-3.5 \%, 95 \%$ CI -3.8 to $-3.1 \%$ ) per year between 2001-2017 (Figure 5).

By sex and age groups, the AAPC indicated a significant reduction for men and women in the age groups from 10 to 


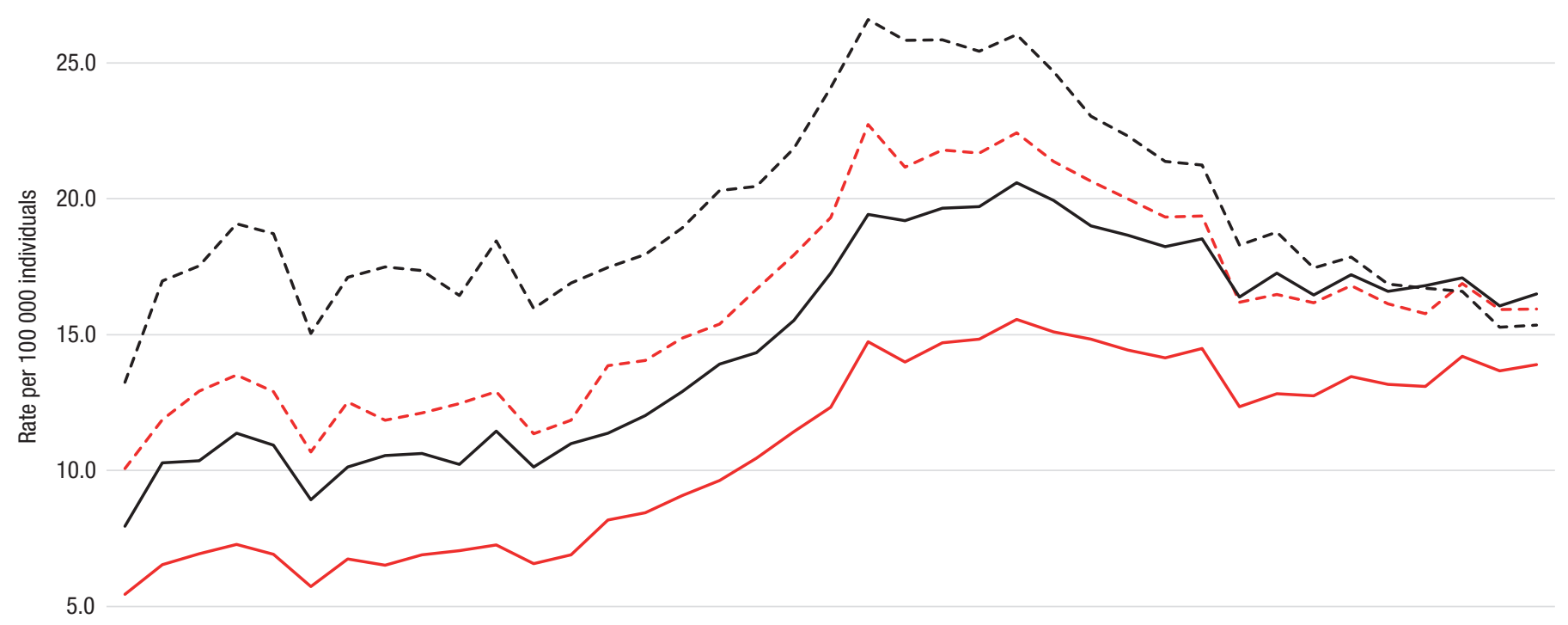

0.0

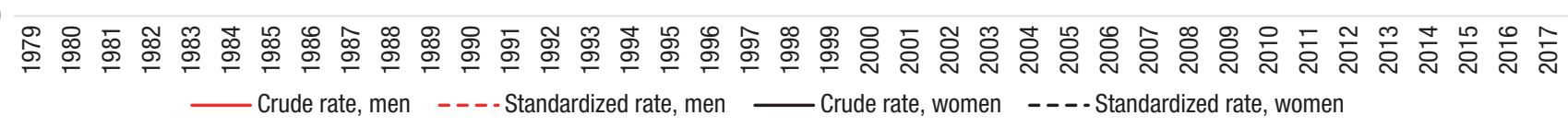

Source: prepared by the authors from the results of the study.

19 years and from 20 to 29 years throughout the whole study period. A significant increase was observed in the group of 80 and over, for both sexes. Regression models showed significant trend adjustments in different joinpoints, both by sex and for each one of the age groups (Figure 5 and Table 2).

Table 2 shows the breakdown of mortality rates changes by age and periods. By age groups, the APC suggested a significant DM mortality decrease in men for ages 10-19, 20-29, 30-39, and 70-79 during periods 1979-2017, 1997-2017, 2001-2017, and 2002-2017, respectively. In women, a significant DM mortality decrease was observed in ages 0-9, 10-19 and 20-29 during period 1979-2017. In men, a significant increase in DM mortality was presented between 1999-2017 for deaths of 80 and over (Table 2).

\section{DISCUSSION}

Our trend analysis on crude and ASMR for DM in Colombian showed a gradual reduction in women between 2000 and 2017, while in men that reduction, less accentuated, was observed for 2004-2017. The crude and ASMR were higher among women except in the last three years of the study period. The crude rates in both women and men were lower than the standardized rates, indicating that age is a confounding factor in mortality from diabetes, and the increase in crude rates may indicate greater aging of the population (life expectancy for women in Colombia went from 66.4 years in 1979 to 76.9 in 2017, and for men from 63.8 years to 74.1 in the same period (16)).
Similar findings were reported in diabetic women who died in Argentina (17).

The higher mortality rates in women may be related to the differential prevalence of risk factors associated with DM. A study carried out in Colombia in 1999 showed that the prevalence of diabetes in the population between 18 and 69 years was higher in women (18). Several more recent studies reported that risk factors continued to be higher in women (19-21). The highest rates observed in women, during most of the analyzed period, may correspond to differences in the distribution of DM risk factors such as diet, physical activity and abdominal obesity (22). These risk factors, combined with the work they do at home (domestic work), and having or not a formal job (23), may not allow the properly care of their health status.

Although it is difficult to compare mortality trends across countries owing to differences in access to health care, standards of clinical care, and diagnostic criteria for DM, our findings are consistent with previously reported trends in some Latin American countries such as Brazil (24), Argentina (17), Panama (25), Cuba (26), Mexico (27), and in other countries as Sweden (28), Serbia (29) and Taiwan (30). However, since 2016, rates for men started to be slightly higher than those for women. This increase may correspond to the differential distribution of risk factors related to the disease and health care, and to the access to healthcare services (17).

The decreasing trend experienced by diabetes-related mortality rates most likely reflects the impact of medical advances 
FIGURE 3. Age-specific mortality rates from diabetes as underlying cause by sex, Colombia, 1979-2017

350.0

300.0

$\frac{\infty}{2}$

200.0

150.0

茫

100.0

50.0

0.0

गे कि

离

芦

क्

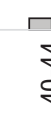$$
\text { ষ্ }
$$

Age groups

$\square$ Men
Women

Source: prepared by the authors from the results of the study.

in the prevention, access, monitoring and treatment of this chronic disease, recognizing that there is still a lack of efforts to enhance the diagnosis of DM, and to improve outpatient care in order to avoid complications (31). Complications can directly influence mortality and morbidity, especially when they occur in the older age whose have increased risk of suffering from pathologies related to aging (32). On the other hand, the trend of mortality rates reduction may be partially explained by having access to early diagnosis, and the strict control of glycemia and related risk factors (33).

The management of diabetes in Colombia has improved with increasingly universal access to the health system (34). Surveys as the "National Health Survey 2007" (NHS) (35) and the "National Survey of Nutrition Status of Colombia 2015" (ENSIN, Spanish acronym) (36) support the decrease in mortality rates in Colombia. The NHS reported that people with DM received care by a general practitioner (96.5\%) and a specialist physician (47.4\%). Regarding to risk factors related to $\mathrm{DM}$, people with the disease received recommendations to quit smoking (more than $76.5 \%$ ), manage stress, reduce weight, perform physical activity, check for glycemia and lipid profiles, and reduce consumption of flour and sugar. In accordance with DM treatments, NHS reported that $61.4 \%$ were treated with insulin or another medication, and $81.6 \%$ received all the medications. $87.4 \%$ of people with DM received control of cholesterol and triglyceride levels and $88.7 \%$ of blood or urine glycemia; $78.9 \%$ did not use methods to measure glycemia at home (35).
Furthermore, ENSIN reported that obesity was more frequent in women $(22.4 \%)$ than in men $(14.4 \%)$; only half of Colombian adults performed 150 minutes of moderate physical activity or 75 minutes of vigorous or strong activity per week, and that 4 out of 10 women and 6 out of 10 men followed this preventive measure (37). ENSIN also showed a reduction in smoking rate, an important risk factor for DM complications, to which a recent program was launched to help tobacco users quit smoking (38).

Efforts have also been made in primary prevention, including public health actions focused on population-based disease prevention, such as food and agricultural policies to facilitate healthy choices, necessary to stop the increase in the incidence of diabetes. Regarding the policies and programs for the promotion and prevention of DM, in the 2000s were defined activities, procedures and conditions required to control the quality and timing of diagnosis, treatment and follow-up of cases. Similarly, implementing the detection of cases of type $2 \mathrm{DM}$ provided timely treatment in order to reduce sequelae, complications and deaths $(39,40)$. Recommendations for good practices, based on the best available clinical evidence and including cost perspectives, patient preferences and the relationship between the benefits and risks of the technologies of interest were also provided in 2015 (41).

Moreover, Colombian healthcare insurers have implemented diabetes promotion and prevention programs in which they include patient education in disease management (nutrition, 
FIGURE 4. Age-specific mortality rates from diabetes as underlying cause, by year and sex, Colombia 1979-2017
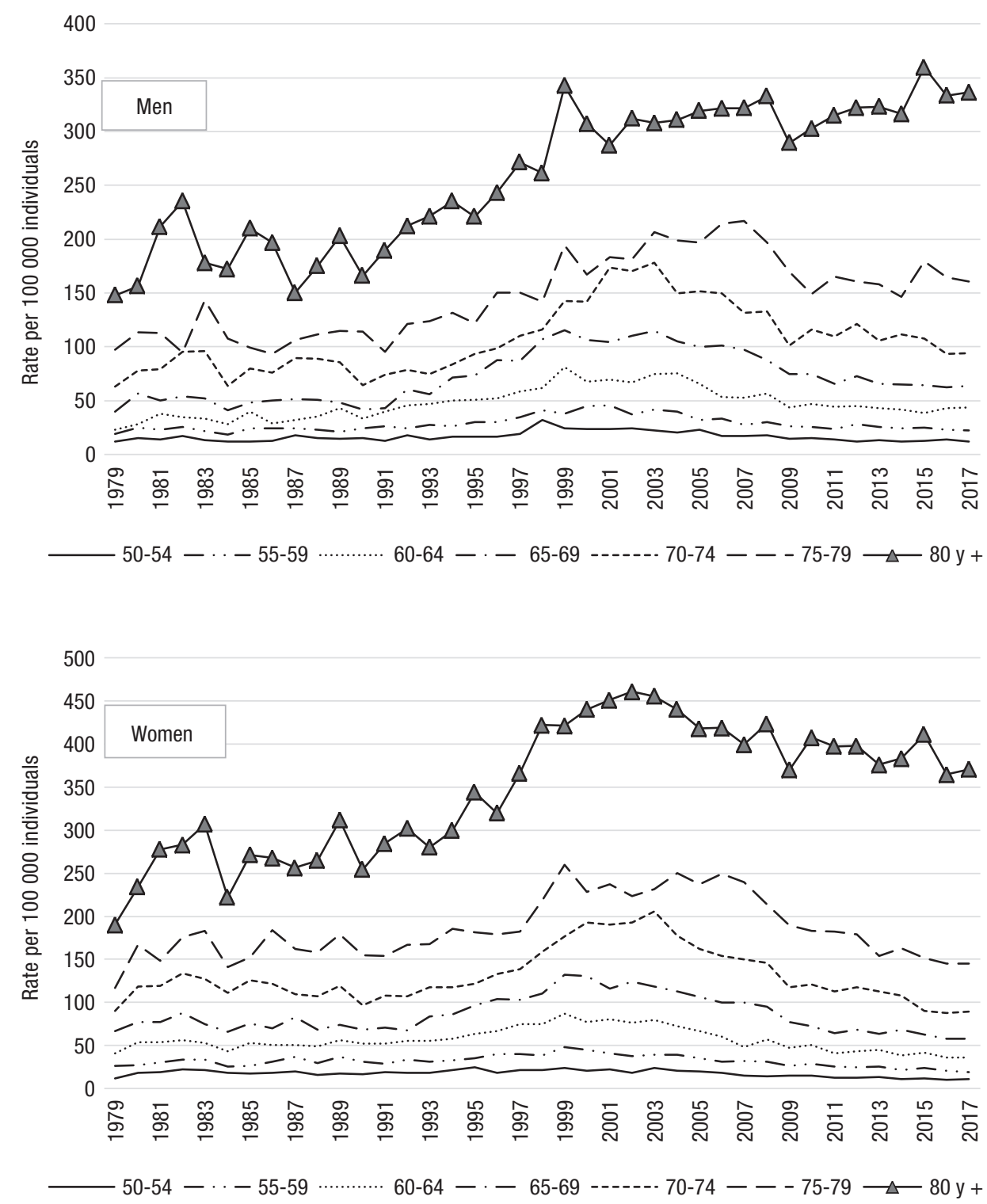

Source: prepared by the authors from the results of the study.

physical activity, pharmacological and non-pharmacological treatment, and the complications of the disease). However, there is still no evidence about the epidemiological impact of these promotion and prevention programs. Likewise, the reduction of trends of DM mortality could be partially attributed to improvements in the standard of living and in the decrease of poverty levels (42).

Our results should be interpreted with caution due to the limitations of the study. Because it is based on secondary data, its coverage and content must be considered. The quality of the information on the underlying cause of DM death taken from the death certificates was rated by the WHO as "average" (43), and it may have been underreported or misclassified. Additionally, it was not possible to discriminate between type 1 and type $2 \mathrm{DM}$ due to the lack of exact information to determine the type of diabetes. Also, it was possible that one of the DM complications had been selected as the underlying cause of death, particularly in the cases of people who died from myocardial infarction, cerebrovascular accident and chronic kidney disease (44). Several studies suggest that mortality due to DM would be up to three times higher than that calculated when it is considered as a underlying cause, and is not taken into account when it appears as a contributing cause of death $(45,46)$. Additionally, it should be mentioned that in Colombia the ICD coding rules for the underlying cause of death changed during the study period. It went from the $9^{\text {th }}$ to the $10^{\text {th }}$ revision of the ICD, although there were no changes in DM coding. It should also be noted that the diagnostic criteria used for the diagnosis of diabetes have been maintained over time, including fasting plasma glucose of $7 \mathrm{mmol} / \mathrm{l}$ (47) and 
FIGURE 5. Age-standardized mortality rates from diabetes as underlying cause, by year and sex, with annual percentage change estimated from joinpoint regression models, Colombia, 1979-2017

30

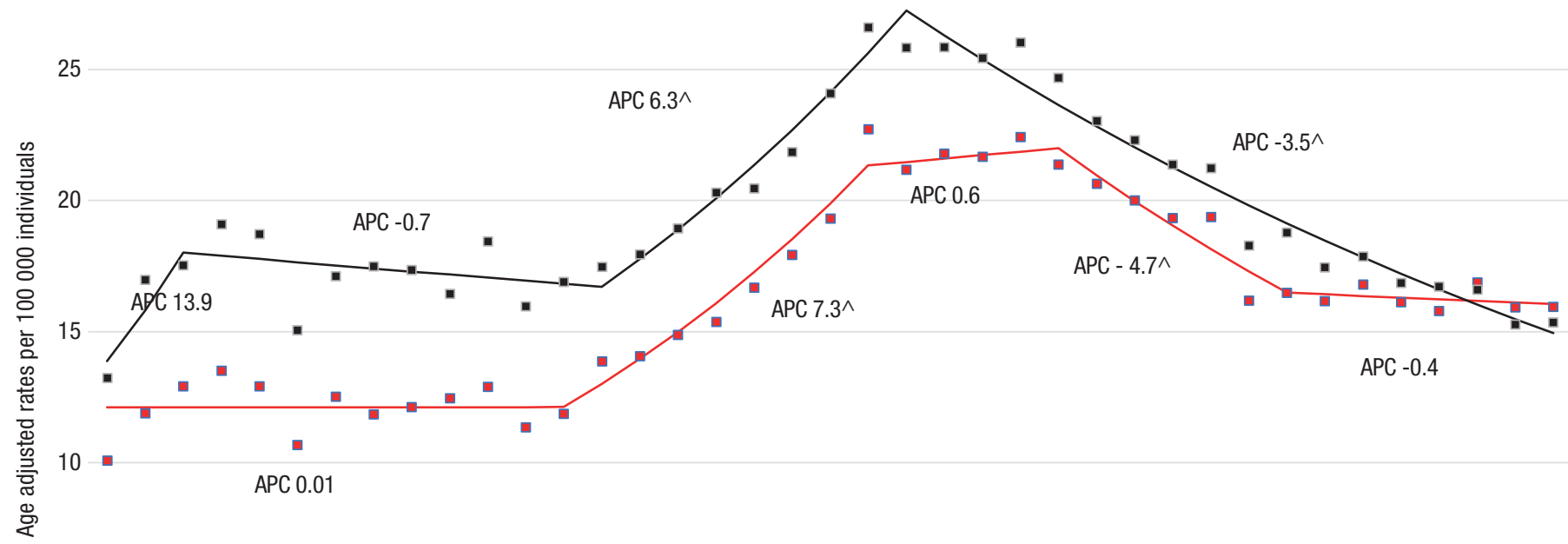

5

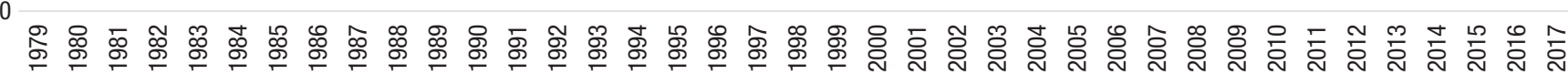
- Estimated rate - men - Standardized rate - men Estimated rate - women — Standardized rate - women

Source: prepared by the authors from the results of the study.

TABLE 2. Joinpoint regression analysis of age-standardized DM mortality rates by sex, Colombia 1979-2017

\begin{tabular}{|c|c|c|c|c|c|c|c|c|}
\hline \multirow{2}{*}{ Age-groups } & \multicolumn{4}{|c|}{ Men } & \multicolumn{4}{|c|}{ Women } \\
\hline & Period & APC $^{a}$ & Trend & AAPC $^{\circ}$ & Period & APC & Trend & AAPC \\
\hline $0-9$ & $1979-2017$ & & & & $1979-2017$ & $-3.2^{\wedge}(-4.4$ to -2.0$)$ & Falling & $-3.2^{\wedge}(-4.4$ to -2.0$)$ \\
\hline $10-19$ & $1979-2017$ & $-4.3^{\wedge}(-5.3$ to -3.4$)$ & Falling & $-4.3^{\wedge}(-5.3$ to -3.4$)$ & $1979-2017$ & $-3.1^{\wedge}(-3.9$ to -3.9$)$ & Falling & $-3.1^{\wedge}(-3.9$ to -3.9$)$ \\
\hline $20-29$ & $1997-2017$ & $-4.3^{\wedge}(-6.1$ to -3.1$)$ & Falling & & & & & \\
\hline $30-39$ & $1979-2001$ & $-0.7(-0.3$ to 1.7$)$ & No change & $-1.2^{\wedge}(-2.0$ to -0.4$)$ & $1979-1993$ & $1.8(-0.1$ to 3.8$)$ & No change & $-0.7(-1.5$ to 0.1$)$ \\
\hline \multirow{4}{*}{$40-49$} & 1990-1999 & $5.5^{\wedge}(2.6$ to 8.6$)$ & Rising & & $1981-1991$ & $-3.8^{\wedge}(-6.0$ to -1.4$)$ & Falling & \\
\hline & $1999-2007$ & $-7.2^{\wedge}(-9.8$ to -4.4$)$ & Falling & $-0.3(-1.4$ to 0.9$)$ & 1991-1998 & 5.6 (1.6 to 9.8$)$ & No change & $-0.2(-2.2$ to 1.8$)$ \\
\hline & $2007-2017$ & $0.4(-1.3$ to 2.2$)$ & Stable & & $1998-2013$ & $-5.0(-5.9$ to -4.1$)$ & No change & \\
\hline & & & & & 2013-2017 & 4.3 (-2.8 to 11.8$)$ & No change & \\
\hline $50-59$ & $1979-1993$ & 0.8 (-0.6 to 2.2$)$ & No change & & $1979-2001$ & $1.7^{\wedge}(1.1$ to 2.3$)$ & Rising & \\
\hline \multirow{4}{*}{$60-69$} & 1990-1999 & $8.9^{\wedge}(6.8$ to 11.1$)$ & Rising & & 1992-1999 & $7.5^{\wedge}(4.9$ to 10.1$)$ & Rising & \\
\hline & 1999-2004 & $0.2(-4.4$ to 4.3$)$ & Stable & & $1999-2003$ & $-1.2(-6.9$ to 4.9$)$ & No change & \\
\hline & $2004-2011$ & $-6.8^{\wedge}(-9.0$ to -4.5$)$ & Falling & $0.7(-0.3$ to 1.8$)$ & $2003-2011$ & $-6.9^{\wedge}(-8.5$ to -5.3$)$ & Falling & -0.7 (-1.7 to 0.2$)$ \\
\hline & 2011-2017 & $-0.9(-3.2$ to 1.5$)$ & No change & & 2011-2017 & $-2.8^{\wedge}(-5.0$ to -0.6$)$ & Falling & \\
\hline
\end{tabular}

(Continued) 


\begin{tabular}{|c|c|c|c|c|c|c|c|c|}
\hline \multirow{2}{*}{ Age-groups } & \multicolumn{4}{|c|}{ Men } & \multicolumn{4}{|c|}{ Women } \\
\hline & Period & $\mathrm{APC}^{\mathrm{a}}$ & Trend & AAPC $^{b}$ & Period & APC & Trend & AAPC \\
\hline \multirow[t]{4}{*}{$70-79$} & 1979-1993 & $0.1(-1.4$ to 1.7$)$ & Stable & & 1979-1982 & $10.1(-3.3$ to 25.3$)$ & No change & \\
\hline & $1993-2002$ & $8.1^{\wedge}(5.6$ to 10.6$)$ & Falling & & $1982-1991$ & $-2.1(-4.3$ to 0.3$)$ & No change & \\
\hline & $2002-2017$ & $-3.0^{\wedge}(-3.7$ to -2.3$)$ & Falling & $0.7(-0.1$ to 1.5$)$ & $1991-2002$ & $-5.7^{\wedge}(4.4$ to 7.0$)$ & Falling & $-0.0(-1.2$ to -1.2$)$ \\
\hline & & & & & $2002-2017$ & $-4.7^{\wedge}(-5.2$ to -4.1$)$ & Falling & \\
\hline$\geq 80$ & $1979-1990$ & $-0.4(-2.6$ to 2.0$)$ & Stable & & 1979-1993 & $1.1(-0.2$ to 2.5$)$ & No change & \\
\hline
\end{tabular}

Source: prepared by the authors from the results of the study.

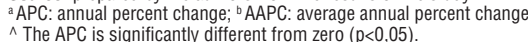

in recent times $\mathrm{HbA} 1 \mathrm{c} \geq 6.5 \%$ (48), so no variations over the time have occurred.

Finally, our study has provided information on the trend of national DM mortality rates in Colombia, for a period of 39 years and it was based on information gathered from death certificates. Promotion and prevention programs must continue to be strengthened for the early diagnosis of individuals with DM. The quality of mortality information should also be improved, regarding to the correct classification of the type of DM and its assignment as the underlying cause of death. The increase in mortality in the older age group and the differences between sexes could indicate an improvement in survival, better diagnosis, and improvement in registration methods.
Author contributions. PCH conceived the original idea. All authors contributed data or analysis tools, interpreted the results, wrote the manuscript, and reviewed the paper. All authors reviewed and approved the final version.

\section{Conflicts of interests. None declared}

Funding. Regular budget of the Observatorio Nacional de Salud, Instituto Nacional de Salud of Colombia.

Disclaimer. The views and opinions in the manuscript are the authors' and do not necessarily reflect the opinion or policy of the RPSP/PAJPH and/or PAHO.

\section{REFERENCES}

1. Saeedi P, Petersohn I, Salpea P, Malanda B, Karuranga S, Unwin $\mathrm{N}$, et al. Global and regional diabetes prevalence estimates for 2019 and projections for 2030 and 2045: Results from the International Diabetes Federation Diabetes Atlas. Diabetes Res Clin Pract. 2019;157:107843.

2. Gómez de la Cámara A, Lapetra J, Castell C, Marín-Ibañez A, García JM, Elosua R, et al. Risk of Cause-Specific Death in Individuals With Diabetes: A Competing Risks Analysis. Diabetes Care. 2016;39(11):1987-95.

3. Centers for Disease Control and Prevention. National diabetes statistics report, 2020. Atlanta, GA: Centers for Disease Control and Prevention - US Department of Health and Human Services; 2020.

4. World Health Organization. Global Report on Diabetes. Geneva: WHO; 2016.

5. Cho NH, Shaw JE, Karuranga S, Huang Y, da Rocha Fernandes JD, Ohlrogge AW, et al. IDF Diabetes Atlas: Global estimates of diabetes prevalence for 2017 and projections for 2045. Diabetes Res Clin Pract. 2018 Apr 1;138:271-81.

6. International Diabetes Federation. IDF Diabetes atlas., 8th edn. Brussels: International Diabetes Federation, 2017. http:/ /www.diabetesatlas.org.

7. Dávila C, Agudelo M, Gloria LE. Diabetes en México y Colombia: análisis de la tendencia de años de vida perdidos, 1998-2007. Rev Salud Pública. 2011;13(4):560-71.

8. Departamento Administrativo Nacional de Estadística de Colombia. Archivo nacional de datos. Estadísticas vitales 1979-2017.

9. Organización Panamericana de la Salud. Manual de la clasificación estadística internacional de enfermedades, traumatismos y causas de defunción. Décima revisión. Washington DC: OPS; 1995.

10. Organizacion Panamericana de la Salud. Clasificación Estadística Internacional de Enfermedades y Problemas Relacionados con la Salud. Décima revisión. Washington DC: OPS; 2003.
11. Departamento Administrativo Nacional de Estadística de Colombia. Series de población.

12. Ahmad OB, Boschi-Pinto C, Lopez AD, Murray CJL, Lozano R, Inoue M. Age standardization of rates: a new WHO standard. GPE Discussion Paper Series; 2001.

13. Eun SJ. Trends in mortality from road traffic injuries in South Korea, 1983-2017: Joinpoint regression and age-period-cohort analyses. Accid Anal Prev. 2020;134:105325.

14. US National Cancer Institute. Methodology for Characterizing Trends.

15. US National Cancer Institute. Joinpoint Trend Analysis Software Version 4.7.0.0.

16. Expansión. Colombia - Esperanza de vida al nacer 2018 [Internet]. 2020 [cited 2020 Aug 25]. Available from: https://datosmacro. expansion.com/demografia/esperanza-vida/colombia\#: :text=La esperanza de vida se eleva en Colombia\&text=Ese año la esperanza de,publicamos la Esperanza de vida

17. Hernández H, Macías G. Análisis de la tendencia temporal de la mortalidad por diabetes mellitus en Argentina, 1990-2013. Rev Panam Salud Publica. 2017;41(5):1-7.

18. Ministerio de Salud. II Estudio Nacional de factores de riesgo de enfermedades crónicas-ENFREC II. Prevalencia de Diabetes Mellitus y Glucosa Alterada en Ayunas; 1999.

19. Nontes Ochoa S, Serna Arrieta K, Estrada Ávila S, Guerra López F, Sánchez I. Caracterización de los factores de riesgo de diabetes mellitus tipo 2 mediante el test de Findrisk en una población de 30 a 50 años de Medellín, Colombia. Med lab [Internet]. 2016 [cited 2020 Aug 25];563-76. Available from: www.edimeco.com

20. Rodríguez LM, Mendoza Charris M, Sirtori AM, Caballero I, Suárez M, Álvarez MA. Riesgo de Diabetes Mellitus tipo 2, Sobrepeso y Obesidad en adultos del Distrito de Barranquilla. Rev Salud Pública y Nutr. 2019;17(4):1-10. 
21. Aschner P. Epidemiología de la diabetes en Colombia. Av en Diabetol. 2010;26(2):95-100

22. Luo J, Hodge A, Hendryx M, Byles JE. Age of obesity onset, cumulative obesity exposure over early adulthood and risk of type 2 diabetes. Diabetologia [Internet]. 2020 Mar 1 [cited 2020 Sep 17];63(3):519-27. Available from: https://doi.org/10.1007 /s00125-019-05058-7

23. Ehrlich U, Möhring K, Drobnič S. What comes after caring? The impact of family care on women's employment. J Fam Issues. 2020;41(9):1387-419.

24. Schmidt MI, Duncan BB, Ishitani L, Da Conceição Franco G, De Abreu DMX, Lana GC, et al. Trends in mortality due to diabetes in Brazil, 1996-2011. Diabetol Metab Syndr. 2015;7(1):1-9.

25. Motta J, Ortega-Paz L, Gordon CA, Gomez B, Castillo E, Ballesteros VH. Diabetes mortality in Panama and related biological and socioeconomic risk factors. Rev Panam Salud Publica. 2013;34(2):114-20.

26. Conesa Gonzalez AI, Díaz Díaz O, Conesa del Río J, Dominguez Alonso E. Mortalidad por diabetes mellitus y sus complicaciones, Ciudad de La Habana, 1990-2002. Rev Cuba Endocrinol. 2010;21(1):35-50.

27. Sánchez-Barriga JJ. Mortality trends from diabetes mellitus in the seven socioeconomic regions of Mexico, 2000-2007. Rev Panam Salud Publica. 2010;28(5):368-75

28. Eliasson $M$, Talbäck $M$, Rosén $M$. Improved survival in both men and women with diabetes between 1980 and 2004 - A cohort study in Sweden. Cardiovasc Diabetol. 2008;7:1-8.

29. Ilic M, Ilic I. Diabetes mortality in Serbia, 1991-2015 (a nationwide study): A joinpoint regression analysis. Prim Care Diabetes. 2017;11(1):78-85.

30. Li HY, Jiang Y Der, Chang $\mathrm{CH}$, Chung $\mathrm{CH}$, Lin BJ, Chuang LM. Mortality trends in patients with diabetes in Taiwan: A nationwide survey in 2000-2009. J Formos Med Assoc. 2012;111(11):645-50.

31. Castaño RA. Modelos de Atención para Diabetes: de lo Ideal a lo Real. In: Cambiando la Diabetes. Bogotá D.C.: Novo Nordisk; 2014. p. 24-42.

32. Domínguez E. Edad de ocurrencia de los fallecimientos por diabetes en Cuba. Rev Cuba Endocrinol. 2013;24(1):3-17.

33. Pildava S, Strele I, Brigis G. The mortality of patients with diabetes mellitus in Latvia 2000-2012. Med. 2014;50(2):130-6.

34. Ministerio de Salud y Protección Social. Comportamiento del aseguramiento [Internet]. 2018 [cited 2020 May 21]. Available from: https: / / www.minsalud.gov.co/proteccionsocial/Regimensubsidiado /Paginas/coberturas-del-regimen-subsidiado.aspx

35. Ministerio de la Protección Social. Encuesta nacional de salud 2007. Colciencias; 2009.

36. Instituto Colombiano de Bienestar Familiar I. ENSIN: Encuesta Nacional de Situación Nutricional 2015 [Internet]. 2018 [cited
2020 Sep 14]. Available from: https://www.icbf.gov.co/bienestar /nutricion/encuesta-nacional-situacion-nutricional

37. Instituto Colombiano de Bienestar Familiar (ICBF), Profamilia, Escuela de Nutricion y Dietética U de A, Instituto Nacional de salud. Encuesta Nacional de la Situación Nutricional en Colombia, 2005.

38. Colombia. Ministerio de Salud y Protección Social. Programa para la cesacion del consumo de tabaco y atención del tabaquismo. Ministerio de Salud y Protección Social. Bogotá D.C.; 2017.

39. Ministerio de Salud. Resolución 412 de 2000. Vol. 2000, Ministerio de Salud; 2000.

40. Ministerio de Salud. Guía de atención de la diabetes tipo 2. Ministerio de Salud. Bogotá D.C.; 2000

41. Ministerio de Salud y Protección Social; Departamento Administrativo de Ciencia Tecnología e Innovación - Colciencias. Guía de práctica clínica para el diagnóstico, seguimiento de la DM tipo 2 en la población mayor de 18 años. Vol. IMSS-191-1, Gpc. Bogotá D.C. 2016.

42. DANE. Boletín técnico Encuesta Nacional de Calidad de Vida (ECV). Bogotá D.C.; 2017.

43. Mathers CD, Fat DM, Inoue M, Rao C, Lopez AD. Counting the dead and what they died from: assessment of global status of cause of death data. Bull World Health Organ. 2005;83:171-7.

44. Morris N, Wang S, Stevens L, Fuller J, Keen H, WHO Multinational Study Group. Mortality and causes of death in the WHO Multinational Study of vascular disease in diabetes. Diabetologia. 2001;44(Suppl 2):S14-21.

45. Balkau B, Papoz L. Certification of cause of death in French diabetic patients. J Epidemiol Community Health. 1992;46(1):63-5.

46. Fedeli U, Zoppini G, Goldoni CA, Avossa F, Mastrangelo G, Saugo M. Multiple causes of death analysis of chronic diseases: the example of diabetes. Popul Health Metr. 2015;13:21.

47. Ministerio de Salud. Resolución 412 de 2000 [Internet]. 2000 [cited 2020Aug22].Availablefrom:https://docs.supersalud.gov.co/Portal Web/Juridica/OtraNormativa/R0412000.pdf

48. Asociación Latinoamericana de Diabetes. Guías ALAD sobre el diagnóstico, control y tratamiento de la diabetes mellitus tipo 2 con medicina basada en evidencia. Rev ALAD. 2013;20.

Manuscript submitted on 29 April 2020; revised version accepted for publication on 21 September 2020 


\section{Tendencias de la mortalidad por diabetes identificadas a partir de los certificados de defunción en Colombia, 1979-2017}

RESUMEN Objetivo. Describir las tendencias de la mortalidad por diabetes mellitus (DM) en Colombia, por sexo y grupo de edad, entre 1979 y 2017.

Métodos. Estudio ecológico con datos de mortalidad del Departamento Administrativo Nacional de Estadística de Colombia. Se estimaron las tasas de mortalidad anuales brutas y ajustadas por edad por cada 100000 personas. Se describieron las tendencias de las tasas ajustadas por sexo y grupos de edad. Se realizaron modelos de regresión joinpoint para estudiar las tendencias de la mortalidad.

Resultados. En el período del estudio, el número total de muertes por DM registradas en Colombia fue de 200 650, el 58\% (116 316) en mujeres ( $p<0,05)$. Las tasas de mortalidad ajustadas por edad, en cada sexo, aumentaron de 13,2 a 26,6 muertes por 100000 en las mujeres y de 10,1 a 22,7 en los hombres entre 1979 y 1999. En el período 1999-2017 se observó una disminución de 26,6 a 15,4 por 100000 en las mujeres y de 22,7 a 15,9 en los hombres. El análisis de regresión joinpoint demostró que el cambio porcentual anual medio del período no varió en ambos sexos (hombres: -0,2\%, IC 95\%-1,0 a 1,4\%; mujeres: 0,7\%, IC 95\% -0,1 a $1,6 \%)$.

Conclusiones. La mortalidad por DM mostró una tendencia decreciente después del año 2000 en las mujeres y del 2004 en los hombres. Es necesario seguir fortaleciendo los programas de prevención primaria y secundaria a fin de alcanzar un diagnóstico más temprano de la diabetes.

Palabras clave Diabetes mellitus; mortalidad; epidemiología; Colombia. 